\title{
Deteksi Penyakit Antraknosa pada Daun Pepaya California Berdasarkan Segmentasi K-Means Clustering dengan Menggunakan Metode Klasifikasi Support Vector Machine
}

\author{
Shinta Siti Sundari ${ }^{1,}$ Asep Sugiharto ${ }^{2,}$ Rizki Nursamsi ${ }^{3}$ \\ Jurusan Teknik Informatika, STMIK Tasikmalaya \\ Jl.R.E. Martadinata No.272 A Tasikmalaya, Telp. (0265) 310830 \\ e-mail: ss.shinta@gmail.com ${ }^{1}$, asepsugiharto@gmail.com ${ }^{2}$ rizkinursamsi01@ gmail.com ${ }^{3}$
}

\begin{abstract}
ABSTRAK
Salah satu faktor yang menyebabkan rendahnya kualitas tanaman pepaya adalah penyakit antraknosa yang menyerang pada daunnya. Perkembangan teknoogi informasi pada bidang pengolahan citra digital memungkinkan untuk melakukan identifikasi penyakit daun pepaya secara otomatis. Proses identifikasi penyakit antraknosa pada daun pepaya diawali dengan proses akusisi citra, kemudian dilakukan pre-processing yaitu resizing untuk menyeragamkan ukuran citra dan proses enhancement untuk melakukan perbaikan kualitas citra terhadap kecerahan citra. Selanjutnya, melakukan perubahan ruang warna dari RGB menjadi $L^{*} a^{*} b$. Setelah melakukan perubahan ruang warna hasil perubahan digunakan sebagai input pada segmentasi citra menggunakan algoritme K-Means. Hasil dari segmentasi yaitu nilai ekstrasi fitur diklasifikasikan menggunakan algoritme Support Vector Machine terhadap data latih untuk diketahui klasifikasi penyakitnya. Pembangunan sistem dalam mengimplementasikan yaitu menggunakan MATLAB R2015a. Berdasarkan uji coba yang dilakukan dan perhitungan akurasi pada penyakit daun pepaya memiliki persentase keakuratan sistem sebesar $96.00 \%$.
\end{abstract}

Kata kunci: Antraknosa, Segmentasi Citra, K-Means clustering, Klasifikasi citra, Support Vector Machine.

\begin{abstract}
One of the factors that causes the low quality of papaya plants is anthracnose disease that attacks the leaves. The development of information technology in the field of digital image processing makes it possible to identify papaya leaf diseases automatically. The process of identifying anthracnose diseases on papaya leaves begins with the process of image acquisition, then pre-processing is resizing to uniform the size of the image and the enhancement process to improve the image quality of the image brightness. Next, change the color space from RGB to $L^{*} a^{*} b$. After making changes to the color space the results of the changes are used as input to image segmentation using the K-Means algorithm. The results of segmentation are feature extraction values classified using the algorithm Support Vector Machine for training data to determine the classification of the disease. System development in implementing that is using MATLAB R2015a. Based on trials conducted and calculation of accuracy in papaya leaf disease has a system accuracy percentage of $96.00 \%$.
\end{abstract}

Keywords: K-Means Clustering, Anthracnose, Image Segmentation, Image Classification, Support Vector Machine. 


\section{PENDAHULUAN}

Menurut Badan Pusat Statistika Kota Banjar pada tahun 2019 Pepaya merupakan salah satu komoditas buah terbesar setelah pisang yang banyak diproduksi. Namun, pada 3 tahun terakhir terdapat masalah dari hasil produksi pepaya, yakni hasil produksi pepaya yang menurun[1]. Faktor utama yang menyebabkan hal tersebut adalah penyakit yang menyerang tanaman pepaya. Salah satu penyakit utama tanaman pepaya ini yaitu penyakit antraknosa yang dapat menyebabkan menurunnya kualitas dan kuantitas buah pepaya[2]. Saat ini cara yang bisa dilakukan untuk mengidentifikasi penyakit tanaman papaya yaitu dengan melihat langsung melalui mata telanjang atau dengan uji laboratorium yang biasanya mengalami kekeliruan atau kurang tepat dan jika dalam jumlah banyak akan membutuhkan waktu yang panjang. Ditambah lagi setiap orang memiliki penilaian yang berbeda-beda terhadap warna.

Untuk membangun sistem, peneliti mencari referensi yang sebelumnya sudah ada. Penelitian yang membahas mengenai permasalah ini yaitu pada jurnal dengan judul "Fault Area Detection in Leaf Diseases using k-means Clustering” Pengaruh penyakit memperlambat produksi makanan. Dalam kebanyakan kasus hama dan penyakit yang ditemukan pada daun atau cabang tanaman. Penyakit daun dapat dideteksi menggunakan gambar sederhana dengan bantuan pengolahan citra dan segmentasi. Metode K-means clustering merupakan metode yang efisien digunakan untuk mendeteksi penyakit[3]. Selanjutnya pada jurnal penelitian dengan judul " Leaf Disease Detection: Feature Extraction with K-means clustering and Classification with ANN" objek penelitian dari aplikasi pengolahan citra digital ini yaitu objek daun kapas dan tomat. Adapun penyakit yang dideteksi yaitu bacterial leaf spot, target spot septoria leaf spot dan leaf mold. Hasil identifikasi deteksi penyakit daun pada aplikasi pengolahan citra digital dengan metode K-Means clustering ini menghasilkan akurasi yang baik dengan rata-rata presentase 92,5\%[4]. Penelitian selanjutnya dengan judul "Leaf Disease Detection on Cucumber Leaves Using Multiclass Support Vector Machine" pendeteksian penyakit dilakukan dengan menggunakan pendekatan Multiclass SVM sebagai pengklasifikasian. Beberapa penyakit pada mentimun yang dianalisa seperti bercak daun, leaf miner, dan CMV. Pre-processing dilakukan pada beberapa gambar, kemudian dilakukan Segmentasi menggunakan metode K-Means dilakukan dengan menggunakan ruang warna L*a*b* sehingga menghasilkan cluster-cluster yang nantinya akan diekstrasi menggunakan GLCM untuk kemudian dilakukan sebuah klasifikasi untuk mendeteksi penyakit daun[5].

Berdasarkan beberapa penelitian tersebut, maka sistem yang akan dibangun ini menerapkan metode K-Means untuk melakukan segmentasi pada citra daun pepaya. Kemudian dilakukan identifikasi penyakit pada daun pepaya yaitu Antraknosa (Anthracnose). Proses identifikasi penyakit daun pepaya diawali dengan akusisi citra, kemudian dilakukan pre-processing berupa proses resizing dan proses enhance. Selanjutnya, dilakukam segmentasi citra untuk didapat nilai ekstrasi fitur dengan GLCM. Kemudian akan di klasifikasikan dengan menggunakan Support Vektor Machine (SVM) yang bisa memisahkan dua set data dari dua kelas yang berbeda menggunakan hyperplane (bidang pemisah). Setelah itu, dilakukan penghitungan tingkat Akurasi berdasarkan hasil dari proses pengujian. Oleh karena itu ,berdasarkan permasalahan yang telah diuraikan tersebut, maka penulis memilih judul penelitian yaitu "DETEKSI PENYAKIT ANTRAKNOSA PADA DAUN PEPAYA CALIFORNIA BERDASARKAN SEGMENTASI K-MEANS CLUSTERING DENGAN MENGGUNAKAN METODE KLASIFIKASI SUPPORT VECTOR MACHINE".

\section{METODE PENELITIAN}

\subsection{Pengumpulan Data}

Pengumpulan data untuk penelitan ini diambil di Perkebunan Pepaya California yang berada di daerah Desa Sinartanjung Kecamatan Pataruman Kota Banjar. Sebanyak 150 data citra daun dikumpulkan dan dibagi menjadi 125 data uji dan 25 data latih. 125 data latih, terdiri dari masing-masing daun dengan kategori sehat dan daun berpenyakit antraknosa. Kemudian 25 data uji juga dibagi menjadi 2 kategori . Cara pengambilan gambar dengan memetik daun dan diletakkan di alat bantu cover berwarna putih sebagi latar belakang. Setelah itu pengambilan gambar pada daun menggunakan kamera smartphone pencahayaan yang merata dengan dimensi 3000x4000 pixel. 


\subsection{Perancangan Algoritma}

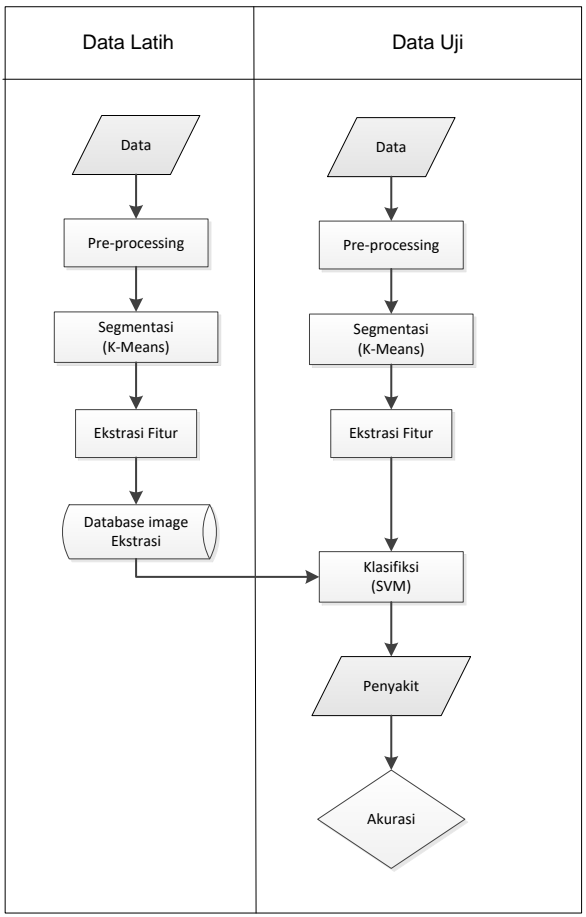

Gambar 1. Desain Sistem

\subsubsection{Akuisisi Data}

Data yang digunakan pada penelitian ini diperoleh dari data citra . yang diambil langsung dari tempat penelitian. Data yang digunakan merupakan data citra daun yang terserang penyakit Antraknosa dan daun sehat. Format data citra yaitu*.jpg dengan total data 150 data. Contoh citra daun yang akan digunakan dapat dilihat pada Gambar berikut .

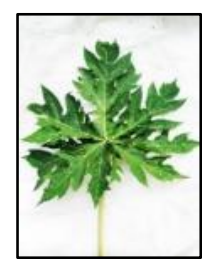

Gambar 2. Daun Sehat

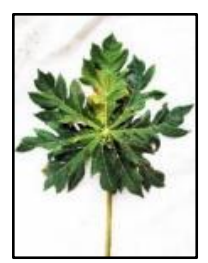

Gambar 3. Antraknosa

\subsubsection{Pre-Processing}

Sebelum dilakukan proses segementasi, citra terlebih dahulu dilakukan praproses. Tahapan proses yang pertama adalah proses Resizing yaitu mengubah ukuran citra menjadi 256 x 256 pixel. Citra yang sudah diubah ukurannya kemudian dilakukan perbaikan kualitas citra dengan proses enhacne yaitu dengan peningkatan kontras. Proses memperkecil ukuran citra dan perbaikan citra dilakukan untuk membuat data input menjadi seragam karena operasi konvolusi hanya bisa dilakukan pada data citra yang memiliki dimensi panjang dan lebar yang sama. 


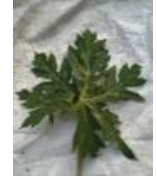

(a)

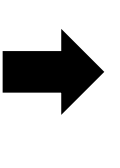

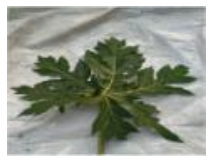

(b)

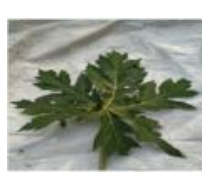

(a)

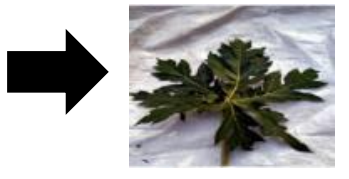

(b)

Gambar 4. Proses resizing

Gambar 5. Proses enhancement

\subsubsection{Segmentasi K-Means}

Dalam penelitian ini, K-means clustering digunakan untuk melakukan memisahkan antar region dalam citra berdasarkan pada perbedaan warna citra. Citra hasil preprocessing yang semula dalam ruang warna RGB dikonversi menjadi ruang warna $\mathrm{L}^{*} \mathrm{a} * \mathrm{~b}$ kemudian dilakukan klustering dengan menggunakan komponen a dan b. Jumlah kluster yang digunakan adalah 3. Kluster 1 direpresentasikan oleh objek berwarna biru, kluster 2 berwarna cyan, dan kluster 3 berwarna kuning. Dari ketiga kluster tersebut dipilih 1 kluster berdasarkan ROI (Region of Interest) atau daerah/bagian tertentu dari citra yang diinginkan.

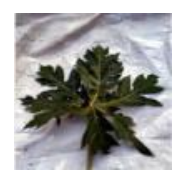

(a)citra hasil preprocessing

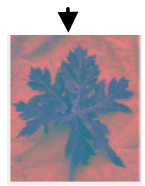

(b) Hasil konversi ruang warna citra

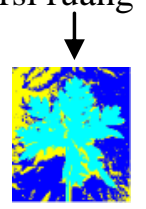

(c)citra hasil segmentasi

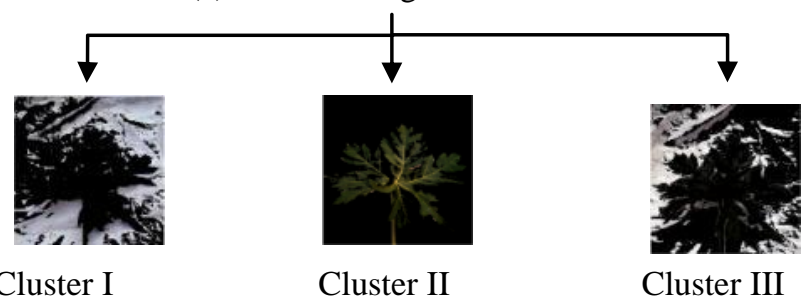

Gambar 6. Proses segmentasi k-means

\subsubsection{Ekstraksi Fitur}

Dari gambar input, fitur harus diekstraksi. Dalam hal ini Ekstraksi tekstur digunakan dalam penelitian ini, Tekstur merupakan salah satu ciri yang bias diekstrak dari suatu citra digital. Tekstur dapat digunakan sebagai ciri yang membedakan gambar satu dengan yang lainnya . metode yang digunakan yaitu GLCM ( Gray-Level Co-Occurrence Matrix). Pada penelitian ini ektraksi dilakukan terhadap citra yang telah dilakukan segmentasi. Ciri GLCM yang diekstrak adalah Contrast, Correlation, Energy, Homogeneity diekstraksi. Dan dengan Menggunakan 
perintah statistic MATLAB ditemukan property/formula lainnya yaitu Mean Standard Deviation, Entropy, RMS, Variance, Smoothness, Kurtosis, Skewness, and IDM.

Kemudian Data hasil ektrasi ini digunakan sebagai data latih yang dimasukan kedalam sebuah set data untuk nantinya digunakan untuk penentuan klasifikikasi citra.

Tabel 1. Data Latih

Ket :

\begin{tabular}{|c|c|c|c|c|c|c|}
\hline $\mathrm{A} 1=$ & Contrast & $\mathrm{A} 5=$ & Mean & $\mathrm{A} 9=$ & Variance & $\mathrm{A} 13=$ \\
\hline $\mathrm{A} 2=$ & Correlation & $\mathrm{A} 6=$ & Standar Deviasi & $\mathrm{A} 10=$ & Smoothness & \\
\hline $\mathrm{A} 3=$ & Energy & $\mathrm{A} 7=$ & Entrophy & $\mathrm{A} 11=$ & Kurtosis & \\
\hline $\mathrm{A} 4=$ & Homogeneti & $\mathrm{A} 8=$ & RMS & $\mathrm{A} 12=$ & skewnes & \\
\hline
\end{tabular}

\subsubsection{Klasifikasi SVM}

Konsep dari SVM yaitu bekerja dengan baik pada set data dengan dimensi tinggi, SVM juga menggunakan teknik kernel harus memetakan data asli dari dimensi asalnya menjadi dimensi lain yang relatif lebih tinggi

\begin{tabular}{|c|c|c|c|c|c|c|c|c|c|c|c|c|c|}
\hline No & A1 & A2 & A3 & A4 & A5 & A6 & A7 & A8 & A9 & A10 & A11 & A12 & A13 \\
\hline 1 & 0.103 & 0.600 & 0.916 & 0.980 & 2.062 & 13.000 & 0.404 & 2.024 & 153.751 & 1 & 61.854 & 7.286 & 255 \\
\hline 2 & 0.171 & 0.738 & 0.790 & 0.964 & 5.817 & 20.590 & 1.060 & 3.918 & 379.572 & 1 & 22.115 & 4.108 & 255 \\
\hline 3 & 0.077 & 0.609 & 0.941 & 0.986 & 1.502 & 11.431 & 0.301 & 1.627 & 124.755 & 1 & 94.982 & 9.005 & 255 \\
\hline 4 & 0.297 & 0.744 & 0.729 & 0.946 & 8.616 & 26.482 & 1.357 & 4.777 & 618.885 & 1 & 17.839 & 3.607 & 255 \\
\hline 5 & 0.442 & 0.733 & 0.726 & 0.933 & 9.469 & 30.746 & 1.360 & 4.826 & 873.122 & 1 & 15.225 & 3.536 & 255 \\
\hline$\ldots$ & $\ldots$ & $\ldots$ & $\ldots$ & $\ldots$ & $\ldots$ & $\ldots$ & $\ldots$ & $\ldots$ & $\ldots$ & $\ldots$ & $\ldots$ & $\ldots$ & $\ldots$ \\
\hline 125 & 0.158 & 0.744 & 0.6163 & 0.951 & 8.743 & 20.828 & 2.029 & 5.877 & 365.753 & 1 & 99.546 & 2.633 & 255 \\
\hline
\end{tabular}

Gambar 7. Margin Hyperplane

Dengan memberikan label -1 untuk kelas pertama dan +1 untuk kelas kedua, maka untuk semua data uji menggunakan persamaan sebagai berikut :

$$
y=\left\{\begin{array}{l}
+1, \text { jika } w . z+b>0 \\
-1, \text { jika } w . z+b<0
\end{array}\right.
$$

\section{HASIL DAN PEMBAHASAN}

\subsection{Hasil}

Tahap implementasi hasil dilakukan dengan menggunakan citra data uji sebagai inputan. Berikut adalah tampilan GUI ( Graphical User Interface ) untuk mendeteksi penyakit antraknosa pada daun pepaya yang dibangun menggunakan MATLAB.

a. Halaman Utama 


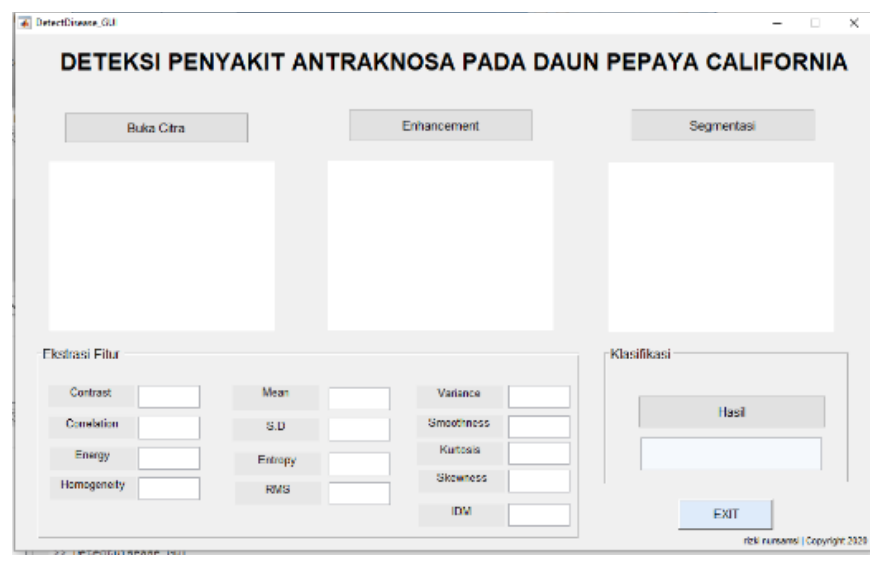

Gambar 8. Halaman Utama

Halaman utama merupakan langkah awal yang digunakan untuk memproses sistem untuk mendeteksi penyakit antraknosa pada daun papaya. Menampilkan tombol-tombol aplikasi yang terdapat dalam sistem guna menjalankan proses deteksi.

b. Proses Image Resizing

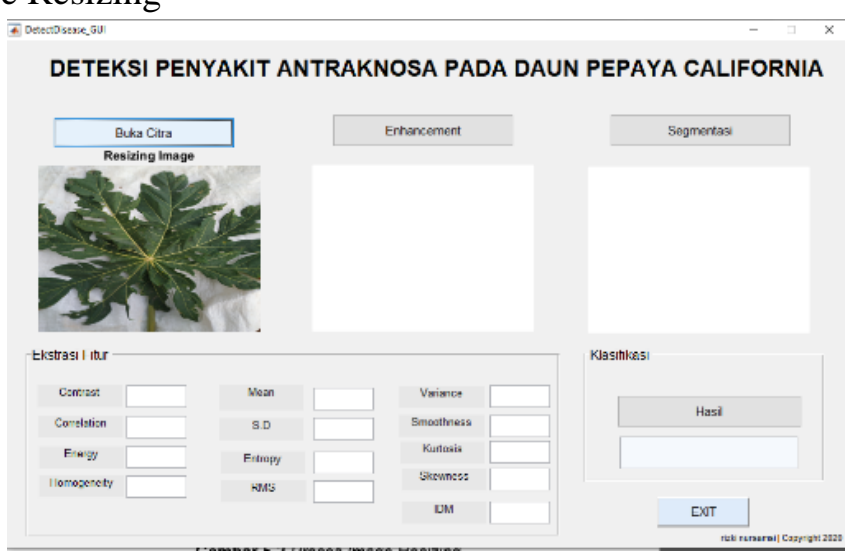

Gambar 9. Proses Image Resizing

Berikut tampilan dari proses image resizing, Tombol "Buka Citra" digunakan untuk membuka file citra dengan format*.jpg . Kemudian ,akan ditampilkan sebuah gambar yang telah ter-resizing.

c. Proses Image Enhance

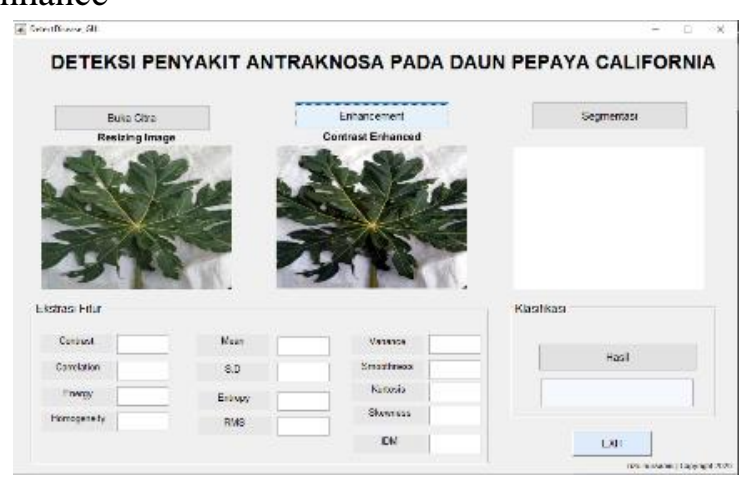

Gambar 10. Proses Image Enhance

Proses yang digunakan untuk menyamaratakan kecerahan gambar, dimana terdapat tombol "Enhancement" yang kemudian akan menampilkan hasil dari proses enhance. 
d. Proses Image Segmentasi

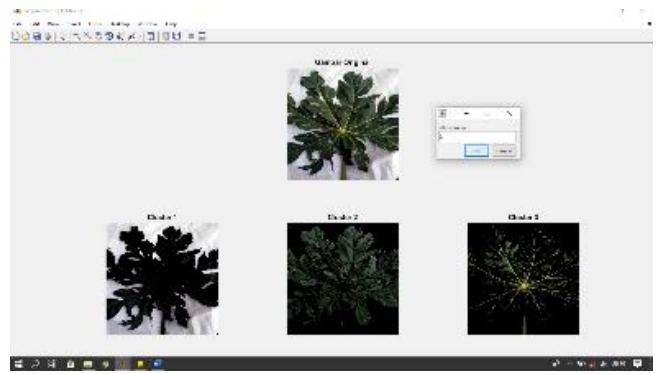

(a)

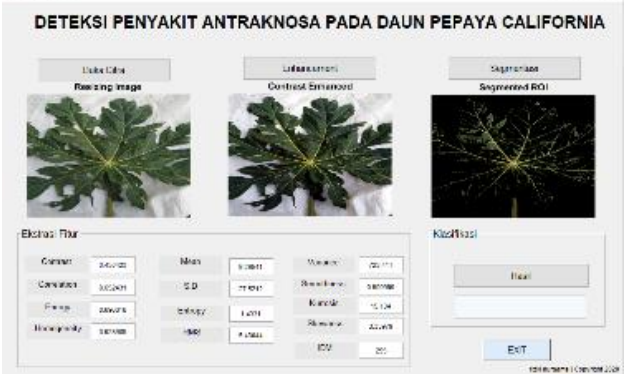

(b)

Gambar 11. Proses Image Segmentasi

Berikut merupakan tampilan proses image segmentasi ,dimana ditampilkan 3 cluster gambar hasil segmentasi (a) yang kemudian dipilih satu untuk melakukan proses berikutnya berdasrkan ROI (b).

\section{e. Proses Ekstrasi}

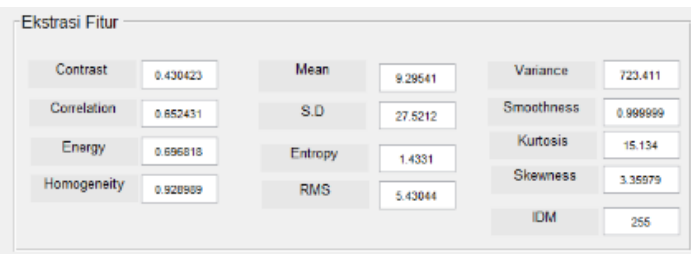

Gambar 12 Proses Ekstraksi

Berikut merupakan tampilan data hasil ekstrasi dari gambar yang telah melalui beberapa proses pengolahan.

f. Proses Klasifikasi

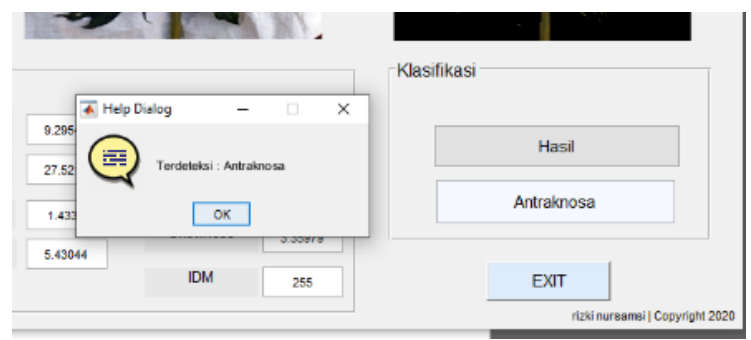

Gambar 14. Proses Klasifikasi

Proses dimana menampilkan hasil klasifikasi berdasarkan pengolahan dan data latih. Menampilkan diaolog dari hasil klasifikasi.

\subsection{Pembahasan}

Hasil pada penelitian ini akan diujikan menggunakan nilai akurasi. Nilai Akurasi diperoleh dengan cara menghitung jumlah data uji yang terklasifikasikan benar dibagi dengan jumlah keseluruhan data uji. Pengujian dilakukan pada data uji sebanyak 25 citra dengan ekstensi .jpg untuk melihat tingkat keberhasilan klasifikasi terhadap model hasil pelatihan. Evaluasi dari kinerja model yang diperoleh didasarkan pada banyaknya data uji yang diprediksi secara benar dan tidak benar oleh model. Hal ini dapat dihitung menggunakan akurasi yang diformulasikan pada persamaan 2 .

$$
\text { Akurasi }=\frac{\text { Jumlah data uji yang teridentifikasi benar }}{\text { jumlah data uji keseluruhan }} \times 100 \%
$$


Tabel 2. Pengujian

\begin{tabular}{|c|c|c|c|c|}
\hline NO & Citra & Kelas & Hasil Klasifikasi & Ket \\
\hline 1 & Citra 1 & $\begin{array}{c}\text { Antraknosa } \\
\text { (Anthracnose) }\end{array}$ & 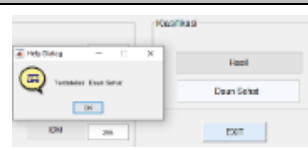 & Salah \\
\hline 2 & Citra 2 & $\begin{array}{c}\text { Antraknosa } \\
\text { (Anthracnose) }\end{array}$ & 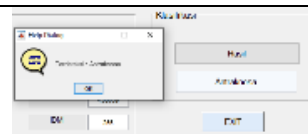 & Benar \\
\hline 3 & Citra 3 & $\begin{array}{l}\text { Daun Sehat } \\
\text { (Healty Leaf) }\end{array}$ & 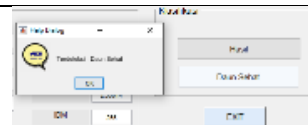 & Benar \\
\hline 4 & Citra 4 & $\begin{array}{l}\text { Daun Sehat } \\
\text { (Healty Leaf) }\end{array}$ & 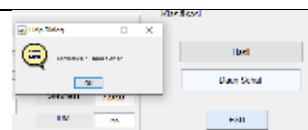 & Benar \\
\hline 5 & Citra 5 & $\begin{array}{l}\text { Daun Sehat } \\
\text { (Healty Leaf) }\end{array}$ & $\frac{\Theta_{n}^{\infty}}{n+1}$ & Benar \\
\hline 6 & Citra 6 & $\begin{array}{l}\text { Daun Sehat } \\
\text { (Healty Leaf) }\end{array}$ & 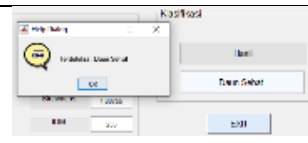 & Benar \\
\hline 7 & Citra 7 & $\begin{array}{c}\text { Antraknosa } \\
\text { (Anthracnose) }\end{array}$ & 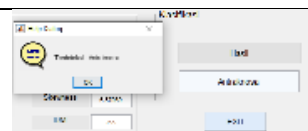 & Benar \\
\hline 8 & Citra 8 & $\begin{array}{l}\text { Daun Sehat } \\
\text { (Healty Leaf) }\end{array}$ & 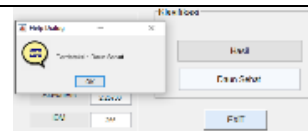 & Benar \\
\hline 9 & Citra 9 & $\begin{array}{l}\text { Daun Sehat } \\
\text { (Healty Leaf) }\end{array}$ & 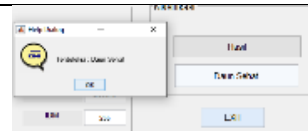 & Benar \\
\hline 10 & $\begin{array}{c}\text { Citra } \\
10\end{array}$ & $\begin{array}{c}\text { Antraknosa } \\
\text { (Anthracnose) }\end{array}$ & 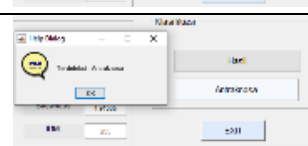 & Benar \\
\hline 11 & $\begin{array}{c}\text { Citra } \\
11\end{array}$ & $\begin{array}{c}\text { Antraknosa } \\
\text { (Anthracnose) }\end{array}$ & 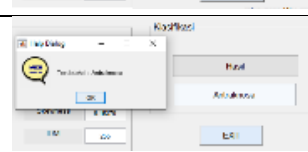 & Benar \\
\hline 12 & $\begin{array}{c}\text { Citra } \\
12\end{array}$ & $\begin{array}{l}\text { Daun Sehat } \\
\text { (Healty Leaf) }\end{array}$ & 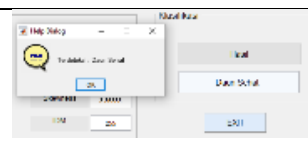 & Benar \\
\hline 13 & $\begin{array}{c}\text { Citra } \\
13\end{array}$ & $\begin{array}{c}\text { Antraknosa } \\
\text { (Anthracnose) }\end{array}$ & 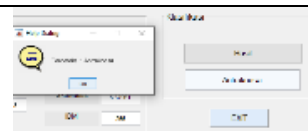 & Benar \\
\hline 14 & $\begin{array}{c}\text { Citra } \\
14\end{array}$ & $\begin{array}{c}\text { Antraknosa } \\
\text { (Anthracnose) }\end{array}$ & 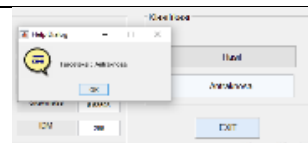 & Benar \\
\hline 15 & $\begin{array}{c}\text { Citra } \\
15\end{array}$ & $\begin{array}{l}\text { Daun Sehat } \\
\text { (Healty Leaf) }\end{array}$ & 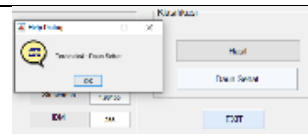 & Benar \\
\hline 16 & $\begin{array}{c}\text { Citra } \\
16\end{array}$ & $\begin{array}{c}\text { Antraknosa } \\
\text { (Anthracnose) }\end{array}$ & 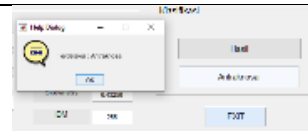 & Benar \\
\hline
\end{tabular}




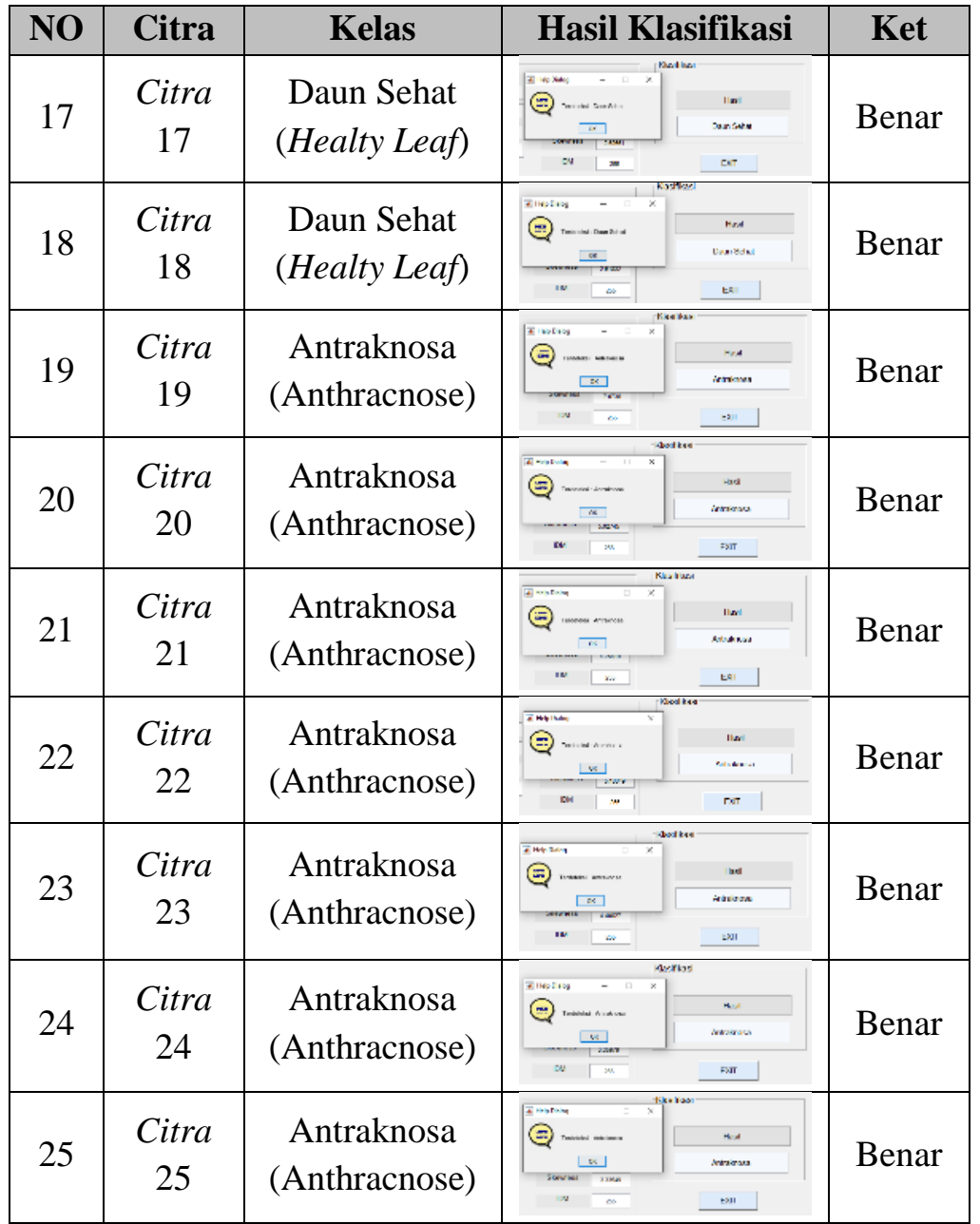

Dari table pengujian diatas dapat ditentukan nilai akurasi pengujian yaitu :

Diketahui :

Banyaknya data $=25$

Hasil sesuai $=24$, Hasil tidak sesuai $=1$

Maka akurasi sistem adalah sebagai berikut : Akurasi $(\%)=\frac{24}{25} \times 100=96$

Dari perhitungan akurasi sistem tersebut didapatkan tingkat akurasi untuk deteksi penyakit antraknosa pada daun papaya california yaitu mencapai $96 \%$.

\section{KESIMPULAN}

Berdasarkan hasil dan pengujian dari Implementasi Deteksi Penyakit Antraknosa pada Daun Pepaya California,maka didapatkan beberapa kesimpulan yaitu :

1. Metode Segmentasi k-means dan Klasifikasi Support Vector Machine dapat digunakan untuk mendeteksi penyakit antraknosa pada daun pepaya melalui beberapa tahapan yaitu Preprocessing citra input yang meliputi proses Resizing, enhancement, dan mengubah ruang warna RGB menjadi $\mathrm{L}^{*} \mathrm{a} * \mathrm{~b} *$. Kemudian melakukan segmentasi menggunakan K-Means untuk proses segmentasi daun dan segmentasi penyakit. langkah yang terakhir adalah klasifikasi menggunakan algoritme SVM.

2. Dengan teknik tersebut sudah dapat melakukan klasifikasi dengan tingkat akurasi sebesar 96,00\% didapat dari pengujian menggunakan 25 data uji. 


\section{SARAN}

Berdasarkan Penelitian yang penulis lakukan pada Implementasi Deteksi Penyakit Antraknosa pada Daun Pepaya California ini, penulis memberikan beberapa saran yang sifatnya membangun untuk pengembangan yang lebih baik lagi bagi penelitian selanjutnya, diantaranya sebagai berikut :

1. Berdasarkan hasil tahap pengujian bahwa tingkat akurasi sebesar $96,00 \%$ sudah memiliki tingkat akurasi yang baik namun belum optimal sehingga perlu mencari dan mencoba pada model algoritma lain yang lebih baik pada penelitian selanjutnya.

2. Sistem dapat dikembangkan dengan penyakit tamanan pada pepaya lebih banyak dan lebih komplit.

3. Penelitian ini dibatasi pada satu citra dengan background warna putih dalam satu citra. Untuk penelitian lanjutan dapat digunakan beberapa daun dan background bebas dalam satu citra.

\section{UCAPAN TERIMA KASIH}

Dengan selesainya penelitian ini, penulis mengucapapkan terimakasih kepada semua pihak yang telah membantu dan berkontribusi dalam penelitian ini, sehingga penelitian ini dapat terlaksana dengan baik dan lancar.

\section{DAFTAR PUSTAKA}

[1] Badan Pusat Statistik Kota Banjar, “Kota Banjar Dalam Angka” 2019.

[2] Ni Luh Putu I, Affandi dan Diah Sunarwati, “ Pengelolaan Kebun Pepaya Sehat” 2008.

[3] Subhajit Maity, Sujan Sarkar, Avinaba Tapadar, Ayan Dutta, Sanket Biswas, Sayon Nayek ,Pritam Saha "Fault Area Detection in Leaf Diseases using k-means Clustering".ICOEI,2018

[4] Ch. Usha Kumari, S. Jeevan Prasad, G. Mounika "Leaf Disease Detection: Feature Extraction with K-means clustering and Classification with ANN".ICCMC,2019

[5] P. Krithika and S. Veni, "Leaf Disease Detection on Cucumber Leaves Using Multiclass Support Vector Machine”. IEEE WISPNET,2017.

[6] Trimi Neha Tete dan Sushma Kamlu, "Detection of Plant Disease Using Threshold, $K$ Mean Cluster and ANN Algorithm”,IEEE ,2018. 